\title{
Antioxidant and Anticancer Activities of Methanol Extract of Melochia corchorifolia L.
}

\author{
Harini .V ${ }^{1}$, Vijayalakshmi .M², Sivaraj . $C^{3}$, Arumugam .P ${ }^{4}$ \\ ${ }^{1,2}$ Department of Biotechnology, Dr. M.G.R Educational and Research Institute, University, Maduravoyal, Chennai-95, Tamil Nadu, India \\ ${ }^{3}$ Postdoctoral Fellow, Department of Natural Products, Armats Biotek Training and Research Institute, Guindy, Chennai-32, Tamil Nadu, \\ India \\ ${ }^{4}$ Armats Biotek Training and Research Institute, Guindy, Chennai-32, Tamil Nadu, India
}

\begin{abstract}
Melochia corchorifolia belongs to the family Sterculiaceae and is a common weed found in many regions throughout tropical and subtropical regions. M. corchorifolia has been traditionally used for several purposes. In folk medicine, in India, the leaves and roots of $M$. corchorifolia are used to treat urinary disorders, abdominal swelling, dysentery and snakebites. The aim of the present study was to investigate the antioxidant and antiproliferative properties of methanol extract of aerial parts of M. corchorifolia. The phytochemical screening was carried out by standard methods which revealed the presence of important phytoconstituents such as alkaloids, terpenoids, steroids, phenolic compounds, flavanoids and glycosides. The antioxidant assays such as $\mathrm{DPPH}^{\circ} \mathrm{radical}$, ABTS ${ }^{\cdot+}$ radical cation, $\mathrm{OH}^{\cdot}$ radical scavenging assays, Phosphomolybdenum reduction and $\mathrm{Fe}^{3+}$ reducing power assays were studied for the methanol extract of M. corchorifolia. Since the results were quite encouraging, thin layer chromatography and GC-MS analysis were performed. The in vitro anticancer activity for MCF7 (breast cancer) cell line was studied by MTT assay method. The IC $C_{50}$ values of $\mathrm{DPPH}^{\bullet}$ radical, $\mathrm{ABTS}^{\cdot+}$ radical cation, $\mathrm{OH}^{\top}$ radical scavenging assays were $35.26,10.50,49.36 \mu \mathrm{g} / \mathrm{mL}$ concentration, respectively. $\mathrm{GC}$ $M S$ analysis revealed the presence of active volatile compounds in the methanol extract of $M$. corchorifolia. The cytotoxic activity for MCF7 cell line was $66.84 \%$ at $100 \mu \mathrm{g} / \mathrm{mL}$ concentration by MTT assay method. The results of this study demonstrate that M. corchorifolia has significant antioxidant and antiproliferative activities. Further studies are required to isolate active compounds and elucidate their mode of action.
\end{abstract}

Keywords: Radical, DPPH', GC-MS, cytotoxicity, MCF7, MTT assay

\section{Introduction}

Breast cancer is the second most common cancer in the world and the most frequent cancer among women. Though the magnitude of breast cancer is lower in India as compared to developed countries, a significant rise is observed in the last two decades in most of the Indian states. ${ }^{[1]}$ Socioeconomic and lifestyle changes such as late childbearing, dietary changes and associated changes in menstrual patterns are believed to be responsible for rising risk of breast cancer in developing countries. ${ }^{[1]}$ A number of factors have been identified which increases the risk of cancer, such as smoking, high consumption of alcohol, obesity, lack of physical exercise, exposure to radiation, chemical mutagens and environmental pollutants.

The risk of breast cancer is slightly reduced when there is a high intake of fruits and vegetables. ${ }^{[2]}$ Many active compounds have been derived from medicinal plants that possess potent efficacy in treating breast cancer and have been successful in clinical trials. Plant extracts obtained from different parts of the plants such as leaves, fruits, stem, bark and root are found to be potent inhibitors of breast cancer. Some of the drugs such as Vinblastine (Catharanthus roseus), Paclitaxel and Docetaxel (Taxus brevifolia), Camptothecin (Camptotheca acuminata) have shown strong antitumor activity in breast cancer and are well tolerated in patients. These drugs obtained from medicinal plants act via several mechanisms such as inhibiting microtubule assembly and thereby preventing cell cycle progression (Vinblastine), inhibiting DNA topoisomerase enzyme (Camptothecin) or possessing antioxidant activity. Melochia corchorifolia L. is a perennial type of herb and used in folk medicine. M. corchorifolia (Chocolate Weed) is a common weed. Traditionally, decoction of leaves and roots is used to treat dysentery, stop vomiting and treat urinary disorders. ${ }^{[3]} M$. corchorifolia is widely used by tribal people but its efficacy has not been proven scientifically. The antioxidant and anticancer activities have been studied to find out the potential medicinal uses of the plant.

\section{Materials and Methods}

\section{Collection of Plant Material}

Aerial parts of Melochia corchorifolia were collected from Thandalam, Chengalpattu, Tamil Nadu, India. The collected aerial parts were shade dried for 15 days in order to remove chlorophyll content and finely ground by the mechanical blender. The powdered material was stored in a container for further use.

\section{Preparation of Crude Extract}

Finely ground plant material was extracted with methanol in the ratio of $1: 10(\mathrm{w} / \mathrm{v})$ in a conical flask for $72 \mathrm{~h}$. The extract was then filtered using filter paper in a separate container. The above process was repeated for two times with the same residue but using fresh solvent. All the supernatants were collected together and then the solvent was removed by rotor evaporator. Dark gummy mass was obtained, weighed and stored in a refrigerator at $4{ }^{\circ} \mathrm{C}$.

\section{Qualitative phytochemical screening procedure}

The methanol extract of aerial parts of $M$. corchorifolia was subjected to preliminary phytochemical screening using standard methods. ${ }^{[4]}$ The methanol extract was screened for different classes of phytoconstituents such as alkaloids, steroids, terpenoids, flavonoids and phenolic compounds using specific standard reagents. ${ }^{[5,6]}$

\section{Volume 6 Issue 1, January 2017




\section{International Journal of Science and Research (IJSR) \\ ISSN (Online): 2319-7064}

Index Copernicus Value (2015): 78.96 | Impact Factor (2015): 6.391

\section{In vitro antioxidant assays}

\section{$\mathrm{DPPH}^{\bullet}$ radical scavenging assay}

The antioxidant activity of methanol extract of aerial parts of $M$. corchorifolia was measured on the basis of the scavenging activity of the stable 1, 1- diphenyl 2picrylhydrazyl (DPPH) free radical. ${ }^{[7]}$ One $\mathrm{mL}$ of $0.1 \mathrm{mM}$ DPPH solution in methanol was mixed with $1 \mathrm{~mL}$ of various concentrations $(10-60 \mu \mathrm{g} / \mathrm{mL})$ of methanol extract of $M$. corchorifolia. The mixture was then allowed to stand for 30 min incubation in dark. Ascorbic acid was used as a standard reference. One $\mathrm{mL}$ methanol with $1 \mathrm{~mL}$ DPPH solution was used as control. The decrease in absorbance was measured using UV-Vis Spectrophotometer at $517 \mathrm{~nm}$. The percentage of inhibition was calculated using the following formula:

$\%$ of DPPH ${ }^{*}$ radical inhibition $=\left[\frac{\text { Control }- \text { Sample }}{\text { Control }}\right] * 100$ $\mathrm{ABTS}^{\cdot+}$ radical cation scavenging assay

The antioxidant capacity was estimated in terms of the ABTS $^{\bullet+}$ radical cation scavenging activity. ${ }^{[8]} \mathrm{ABTS}^{\bullet+}$ was obtained by reacting $7 \mathrm{mM}$ ABTS stock solution with 2.45 $\mathrm{mM}$ potassium persulfate and the mixture was left to stand in the dark at room temperature for 12-16 h before use. The ABTS solution (stable for 2 days) was diluted with $5 \mathrm{mM}$ phosphate buffered saline ( $\mathrm{pH}$ 7.4) to an absorbance of $0.70 \pm 0.02$ at $730 \mathrm{~nm}$. After the addition of methanol extract of varying concentrations $(10-60 \mu \mathrm{g} / \mathrm{mL})$ to $1 \mathrm{~mL}$ of diluted ABTS $^{\bullet+}$ solution, the absorbance was measured after 10 min. The $\mathrm{ABTS}^{\bullet+}$ radical-scavenging activity of the samples was expressed as

$\%$ of $\mathrm{ABTS}^{\cdot+} \begin{gathered}\text { radical cation } \\ \text { inhibition }\end{gathered}=\left[\begin{array}{c}\text { Control - Sample } \\ \text { Control }\end{array}\right] 100$

\section{Hydroxyl radical $\left(\mathrm{OH}^{\circ}\right)$ scavenging activity}

The hydroxyl radical scavenging capacity of methanol extract of aerial parts of $M$. corchorifolia was evaluated by the method described by Olabinri et al. ${ }^{[9]}$ Various concentrations $(10-60 \mu \mathrm{g} / \mathrm{mL})$ of methanol extract of aerial parts of $M$. corchorifolia were added with $1.0 \mathrm{~mL}$ of iron- EDTA solution $(0.13 \%$ ferrous ammonium sulphate and $0.26 \%$ EDTA), $0.5 \mathrm{~mL}$ of EDTA solution $(0.018 \%)$ and $1.0 \mathrm{~mL}$ of dimethyl sulphoxide (DMSO) $(0.85 \% \mathrm{v} / \mathrm{v}$ in 0.1 $\mathrm{M}$ phosphate buffer, $\mathrm{pH}$ 7.4). The reaction was initiated by adding $0.5 \mathrm{~mL}$ of ascorbic acid $(0.22 \%)$ and incubated at 80 $90^{\circ} \mathrm{C}$ for $15 \mathrm{~min}$ in water bath. After incubation, the reaction was terminated by the addition of $1.0 \mathrm{~mL}$ of ice- cold TCA $(17.5 \% \mathrm{w} / \mathrm{v})$. Three $\mathrm{mL}$ of Nash reagent $(75.0 \mathrm{~g}$ of ammonium acetate, $3.0 \mathrm{~mL}$ of glacial acetic acid and $2 \mathrm{~mL}$ of acetyl acetone were mixed and made up to $1 \mathrm{~L}$ with distilled water) was added and left at room temperature for $15 \mathrm{~min}$. The reaction mixture without sample was used as control. The intensity of the colour formed was measured Spectroscopically at $412 \mathrm{~nm}$. Ascorbic acid was used as the standard reference. The percentage of inhibition was calculated using the following formula:
$\%$ of $\mathrm{OH}^{*}$ radical inhibition $=\left[\frac{\text { Control }- \text { Sample }}{\text { Control }}\right] * 100$

Phosphomolybdenum reduction assay

The antioxidant capacity of methanol extract of aerial parts of $M$. corchorifolia was assessed as described by Prieto et $a l{ }^{[10]}$ The methanol extract of aerial parts of $M$. corchorifolia with concentrations ranging from 10 to 60 $\mu \mathrm{g} / \mathrm{mL}$ was combined with reagent solution containing ammonium molybdate $(4 \mathrm{mM})$, sodium phosphate $(28 \mathrm{mM})$ and sulphuric acid $(600 \mathrm{mM})$. The reaction mixture was incubated in water bath at $90^{\circ} \mathrm{C}$ for $90 \mathrm{~min}$. The absorbance of the coloured complex was measured at $695 \mathrm{~nm}$. Ascorbic acid was used as the standard reference.

\section{Ferric $\left(\mathrm{Fe}^{3+}\right)$ reducing power assay}

The reducing power of methanol extract of aerial parts of $M$. corchorifolia was determined by the slightly modified method of Yen and Chen, 1995. ${ }^{[11]}$ One $\mathrm{mL}$ of plant extract of different concentrations $(10-60 \mu \mathrm{g} / \mathrm{mL})$ was mixed with phosphate buffer $(1 \mathrm{~mL}, 0.2 \mathrm{M}, \mathrm{pH} 6.6)$ and potassium ferricyanide $\left[\mathrm{K}_{3} \mathrm{Fe}(\mathrm{CN})_{6}\right](1 \mathrm{~mL}, 1 \%)$. The mixtures were then incubated at $50^{\circ} \mathrm{C}$ for $20 \mathrm{~min}$. One $\mathrm{mL}$ of trichloroacetic acid $(10 \%)$ was added to each mixture. Then to the mixture $1 \mathrm{~mL}$ of $\mathrm{FeCl}_{3}(0.1 \%)$ was added and the absorbance was measured at $700 \mathrm{~nm}$ using Spectrophotometer. Ascorbic acid was used as the standard reference.

\section{Thin layer chromatography}

Thin layer chromatography (TLC) was carried out for methanol extract of aerial parts of $M$. corchorifolia on Merck TLC aluminium sheets, silica gel 60 F254 (20 x 20 $\mathrm{cm})$, precoated plates. ${ }^{[12,13]}$ The extract was spotted at 0.3 $\mathrm{mm}$ from the bottom of the TLC plate. The chromatogram was developed in a mixture of the suitable solvent system. The spots were visualized with UV light at $356 \mathrm{~nm}$. The Rf values of the coloured spots were recorded. The ratio in which distinct bands appeared was optimized and $\mathrm{Rf}$ values were calculated.

Calculation of Rf value:

Rf value $=$ Distance travelled by solute/ Distance travelled by solvent

\section{Gas chromatography-Mass Spectrometry (GC-MS)}

For GC-MS analysis, the samples were injected into an HP-5 column (30 m X $0.25 \mathrm{~mm}$ i.d with $0.25 \mu \mathrm{m}$ film thickness), Agilent technologies $6890 \mathrm{~N}$ JEOL GC Mate II GC-MS model. Following chromatographic conditions were used: Helium as carrier gas, flow rate of $1 \mathrm{~mL} / \mathrm{min}$; and the injector was operated at $200^{\circ} \mathrm{C}$ and column oven temperature was programmed as $50-250^{\circ} \mathrm{C}$ at a rate of $10^{\circ} \mathrm{C} / \mathrm{min}$ injection mode. Following MS conditions were used: ionization voltage of $70 \mathrm{eV}$; ion source temperature of $250^{\circ} \mathrm{C}$; interface temperature of $250^{\circ} \mathrm{C}$; mass range of 50 600 mass units.

\section{Identification of components}

The database of National Institute Standard and Technology (NIST) having more than 62,000 patterns was used for the interpretation of mass spectrum of GC-MS. The mass 


\section{International Journal of Science and Research (IJSR) \\ ISSN (Online): 2319-7064}

Index Copernicus Value (2015): 78.96 | Impact Factor (2015): 6.391

spectrum of the unknown component was compared with the spectrum of the known components stored in the NIST library.

Cytotoxic activity of methanol extract of $M$. corchorifolia on MCF7 (human breast cancer) cell line

Cell viability was measured with the conventional MTT reduction assay method as described by Mossman, $1983^{[14]}$ with slight modification. Briefly, MCF7 cells were seeded at a density of $5 \times 10^{3}$ cells/well in 96-well plates for $24 \mathrm{~h}$ in $200 \mu \mathrm{L}$ of RPMI with $10 \%$ FBS. Then culture supernatant was removed and RPMI containing various concentrations $(0.781-100 \mu \mathrm{g} / \mathrm{mL})$ of test compound were added and incubated for $48 \mathrm{~h}$. After treatment cells were incubated with MTT $(10 \mu 1,5 \mathrm{mg} / \mathrm{mL})$ at $37^{\circ} \mathrm{C}$ for $4 \mathrm{~h}$ and then with DMSO at room temperature for $1 \mathrm{~h}$. The plates were read at $595 \mathrm{~nm}$ on a scanning multi-well Spectrophotometer.

\section{Statistical analysis}

All the experiments were conducted in triplicates and data given in tables were average of three replicates. All data were reported as the mean \pm standard deviation of three replicates.

\section{Results}

\section{Phytochemical Screening}

The phytochemical analysis was carried out according to the standard procedure. The results showed the presence of alkaloids, terpenoids, steroids, phenolic compounds, flavanoids and glycosides in the methanol extract of aerial parts of M. corchorifolia.

Table 1: Qualitative analysis of methanol extract of aerial parts of $M$. corchorifolia

\begin{tabular}{|c|c|c|c|}
\hline S. No & Phytochemical Constituents & Test & Result \\
\hline 1 & Alkaloids & Mayer's test & + \\
\hline 2. & Terpenoids & Salkowski test & + \\
\hline 3. & Steroids & Liebermann's test & + \\
\hline 4. & Phenolic Compounds & Ferric chloride test & + \\
\hline 5. & Flavanoids & NaOH test & + \\
\hline 6. & Glycosides & Keller-Kiliani's test & + \\
\hline 7. & Saponins & Foam test & - \\
\hline
\end{tabular}

\section{$\mathrm{DPPH}^{\bullet}$ radical scavenging assay}

The ability of methanol extract of $M$. corchorifolia to scavenge free radicals formed was assessed using 1,1diphenyl-2-picrylhydrazyl radical (DPPH). The maximum $\mathrm{DPPH}^{\circ}$ radical scavenging activity was $76.19 \%$ at $60 \mu \mathrm{g} / \mathrm{mL}$. The methanol extract of $M$. corchorifolia demonstrated a high capacity for scavenging free radicals by reducing the stable DPPH (1,1-diphenyl-2-picrylhydrazyl) radical to the yellow coloured 1,1-diphenyl-2-picrylhydrazine and the reducing capacity increased with increasing concentration of the extract (Table 2, Figure 1). The $\mathrm{IC}_{50}$ value was found to be $35.26 \mu \mathrm{g} / \mathrm{mL}$ concentration and was compared with standard ascorbic acid ( $\mathrm{IC}_{50}=11.98 \mu \mathrm{g} / \mathrm{mL}$ concentration $)$.

\section{$\mathrm{ABTS}^{\cdot+}$ radical cation scavenging assay}

ABTS $^{\circ+}$ is a blue chromophore produced by the reaction between ABTS and potassium persulfate and in the presence of the plant extract or ascorbic acid, preformed cation radical gets reduced and the remaining radical cation concentration was then quantified. The maximum $\mathrm{ABTS}^{\circ+}$ radical cation scavenging activity was $91.26 \%$ at $60 \mu \mathrm{g} / \mathrm{mL}$ concentration. The experiment demonstrated high antioxidant activity with $\mathrm{IC}_{50}$ of $10.50 \mu \mathrm{g} / \mathrm{mL}$ concentration (Table 2, Figure 1) and was compared with standard ascorbic acid $\left(\mathrm{IC}_{50}=4.21\right.$ $\mu \mathrm{g} / \mathrm{mL}$ concentration).

\section{Hydroxyl $\left(\mathrm{OH}^{\circ}\right)$ radical scavenging activity}

The hydroxyl radical is a highly reactive free radical formed in a biological system and reacts with a wide range of molecules found in living cells, such as sugars, amino acids, lipids and nucleotides. Scavenging of hydroxyl radical is an important antioxidant activity. The maximum hydroxyl radical scavenging activity was $55.92 \%$ at $60 \mu \mathrm{g} / \mathrm{mL}$ concentration. This experiment also showed reliable antioxidant activity with $\mathrm{IC}_{50}$ of $49.36 \mu \mathrm{g} / \mathrm{mL}$ concentration (Table 2, Figure 1) and was compared with standard ascorbic acid $\left(\mathrm{IC}_{50}=3.26 \mu \mathrm{g} / \mathrm{mL}\right.$ concentration $)$. The methanol extract of aerial parts of $M$. corchorifolia significantly inhibited generation of $\mathrm{OH}^{\circ}$ radicals in a dosedependent manner.

\section{Phosphomolybdenum reduction assay}

The total antioxidant activity of the methanol extract of aerial parts of $M$. corchorifolia was measured Spectrophotometrically by phophomolybdenum reduction method which is based on the reduction of Mo (VI) by the methanol extract of $M$. corchorifolia and the subsequent formation of green phosphate/Mo (V) complex at acidic $\mathrm{pH}$, with a maximum absorption at $695 \mathrm{~nm}$. The maximum absorbance was 0.331 at $60 \mu \mathrm{g} / \mathrm{mL}$ concentration (Table2, Figure 2). It was compared with standard ascorbic acid (absorbance 0.359).

\section{Ferric $\left(\mathrm{Fe}^{3+}\right)$ reducing power activity}

The reducing power of $\mathrm{Fe}^{3+}$ to $\mathrm{Fe}^{2+}$ by the methanol extract of aerial parts of $M$. corchorifolia was studied and showed reduction ability in a dose-dependent manner (Table 2, Figure 2). The maximum absorbance was 0.752 at $60 \mu \mathrm{g} / \mathrm{mL}$ and was compared with standard ascorbic acid (absorbance 0.289).

Table 2: Antioxidant activities of methanol extract of $M$. corchorifolia

\begin{tabular}{|c|c|c|c|c|c|c|}
\hline \multirow[t]{2}{*}{ S. No } & \multirow{2}{*}{$\begin{array}{c}\text { Concentration } \\
(\mu \mathrm{g} / \mathrm{mL})\end{array}$} & \multicolumn{3}{|c|}{$\%$ of Inhibition } & \multirow{2}{*}{$\begin{array}{l}\text { Phosphomolybdenum } \\
\text { Reduction@695 nm }\end{array}$} & \multirow{2}{*}{$\begin{array}{c}\mathrm{Fe}^{3+} \text { Reducing Power } \\
\text { @ } 700 \mathrm{~nm}\end{array}$} \\
\hline & & $\mathrm{DPPH}^{\circ}$ & $\mathrm{ABTS}^{\cdot+}$ & $\mathrm{OH}$ & & \\
\hline 1 & 10 & $17.5 \pm 1.22$ & $47.59 \pm 3.33$ & $16.66 \pm 1.16$ & $0.157 \pm 0.010$ & $0.242 \pm 0.016$ \\
\hline 2 & 20 & $20.1 \pm 1.40$ & $56.76 \pm 3.97$ & $27.41 \pm 1.92$ & $0.257 \pm 0.017$ & $0.368 \pm 0.025$ \\
\hline 3 & 30 & $42.54 \pm 2.97$ & $75.54 \pm 5.28$ & $36.62 \pm 2.56$ & $0.309 \pm 0.021$ & $0.466 \pm 0.032$ \\
\hline 4 & 40 & $59.51 \pm 4.16$ & $81.66 \pm 5.71$ & $42.76 \pm 2.99$ & $0.317 \pm 0.022$ & $0.556 \pm 0.038$ \\
\hline 5 & 50 & $62.04 \pm 4.34$ & $86.46 \pm 6.05$ & $50.65 \pm 3.54$ & $0.323 \pm 0.023$ & $0.684 \pm 0.047$ \\
\hline 6 & 60 & $76.19 \pm 5.33$ & $91.26 \pm 6.33$ & $55.92 \pm 3.91$ & $0.331 \pm 0.023$ & $0.752 \pm 0.052$ \\
\hline
\end{tabular}

Volume 6 Issue 1, January 2017 


\section{International Journal of Science and Research (IJSR) \\ ISSN (Online): 2319-7064}

Index Copernicus Value (2015): 78.96 | Impact Factor (2015): 6.391

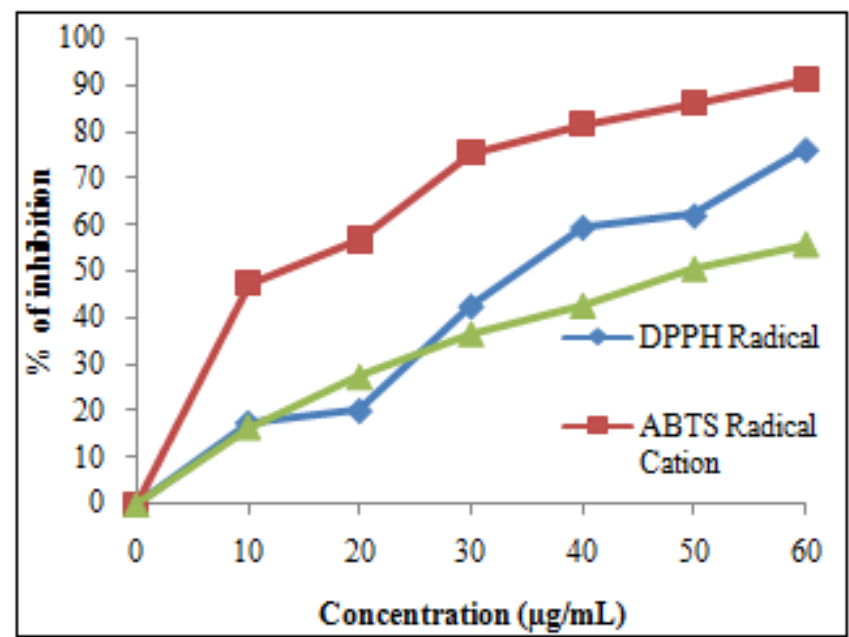

Figure 1: $\mathrm{DPPH}^{\cdot}, \mathrm{ABTS}^{\cdot+}, \mathrm{OH}^{*}$ scavenging activities of methanol extract of $M$. corchorifolia

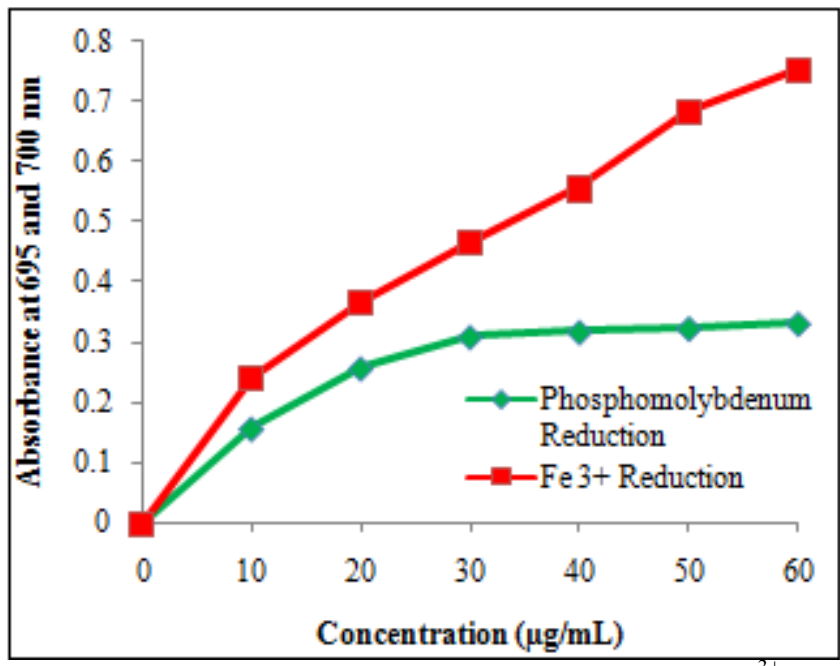

Figure 2: Phosphomolybdenum reduction and $\mathrm{Fe}^{3}$ reducing power activities of methanol extract of $M$. corchorifolia
Thin layer chromatography analysis was carried out in the solvent system of Toluene:Chloroform:Methanol with the ratio of 1.5:1:0.5. The separated compounds in TLC were showed in Figure 3.

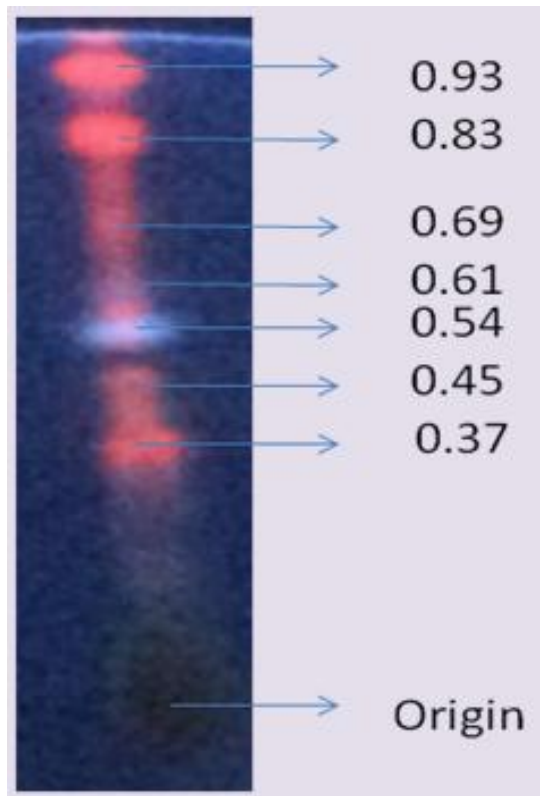

Figure 3: Compounds separated by Thin Layer Chromatography

\section{GC-MS analysis}

GC-MS analysis was carried out for the methanol extract of aerial parts of $M$. corchorifolia and the eluted compounds were showed in Table 3. A flavone compound (5,7dihydroxy-3-phenylchromen-4-one) was eluted by GC-MS. Flavone is a potent antioxidant compound and could be one of the reasons for the antioxidant property of the extract.

\section{Thin Layer Chromatography}

Table 3: Active compounds identified in the methanol extract of aerial parts of $M$. corchorifolia by GC-MS analysis

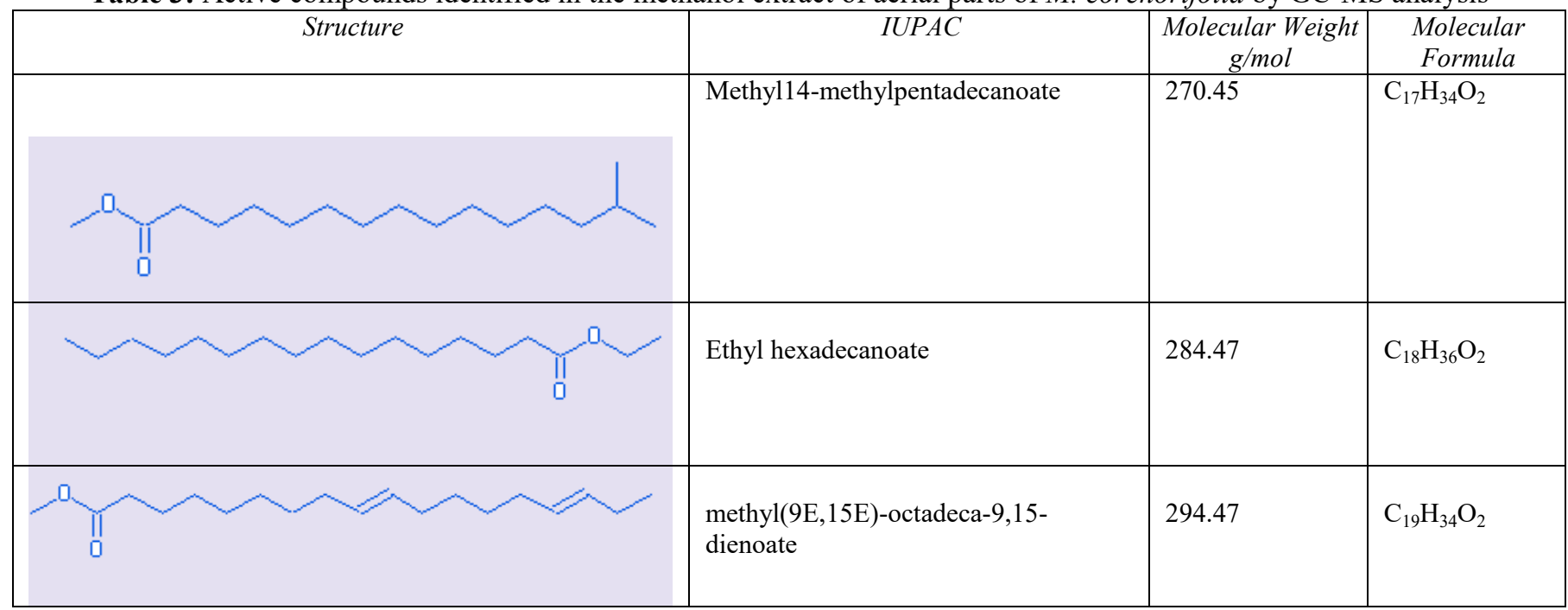

Volume 6 Issue 1, January 2017

www.ijsr.net 
International Journal of Science and Research (IJSR)

ISSN (Online): 2319-7064

Index Copernicus Value (2015): 78.96 | Impact Factor (2015): 6.391

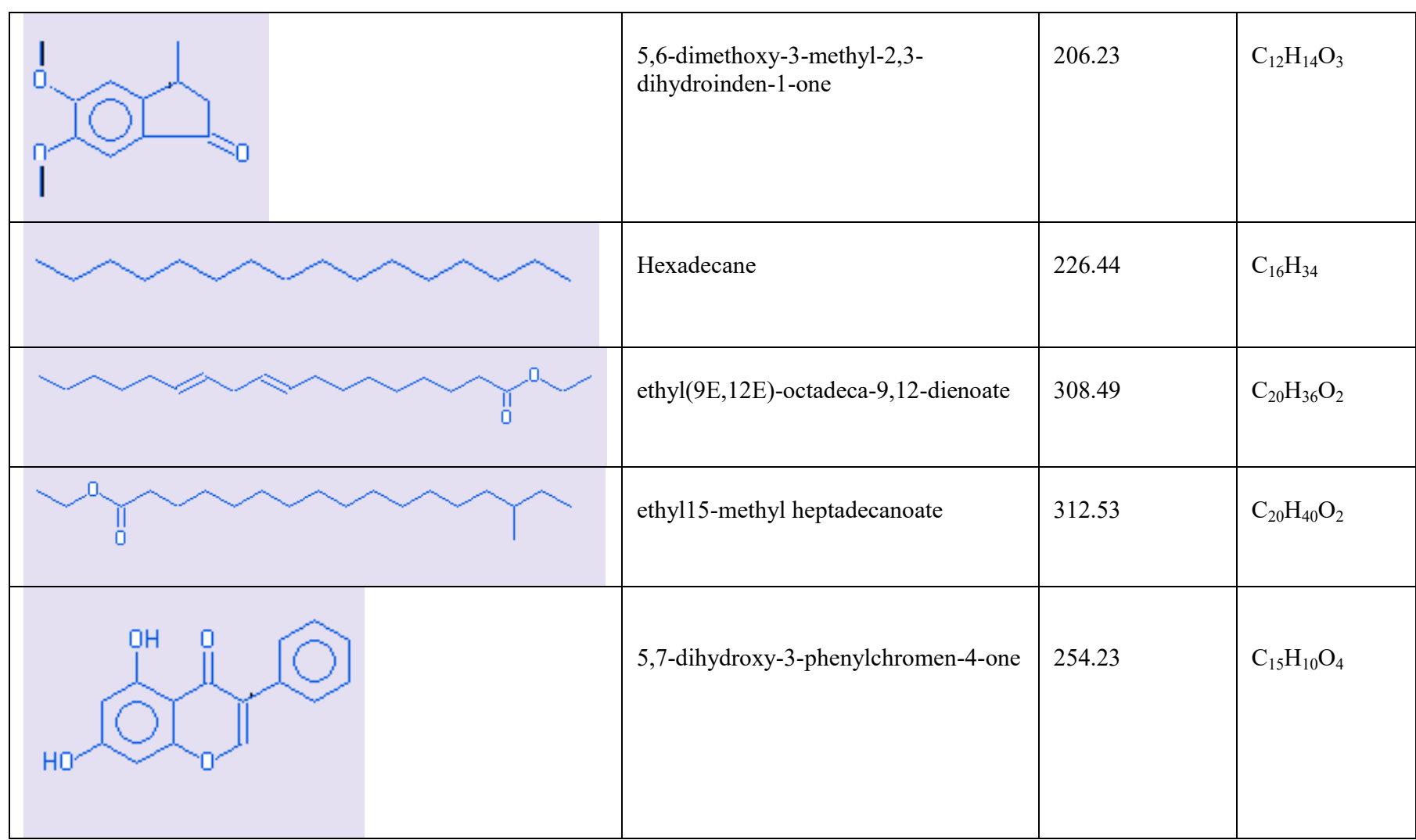

\section{MTT assay}

Cytotoxic activity was studied for the methanol extract of aerial parts of $M$. corchorifolia by MTT assay method. The morphology of MCF7 cells progressively changed from 12.5 $\mu \mathrm{g} / \mathrm{mL}$ to $100 \mu \mathrm{g} / \mathrm{mL}$ concentration of the extract and was compared with control. The maximum cell death was $66.84 \%$ at $100 \mu \mathrm{g} / \mathrm{mL}$ concentration (Table 4, Figure 4).
Table 4: Cytotoxic activity of methanol extract of aerial parts of $M$. corchorifolia

\begin{tabular}{|c|c|c|}
\hline S. No & Concentration $(\mu \mathrm{g} / \mathrm{mL})$ & \% of cell death \\
\hline 1 & 0.781 & $8.38 \pm 1.02$ \\
\hline 2 & 1.562 & $29.26 \pm 0.68$ \\
\hline 3 & 3.125 & $34.83 \pm 3.33$ \\
\hline 4 & 6.25 & $44.16 \pm 3.20$ \\
\hline 5 & 12.5 & $54.14 \pm 1.71$ \\
\hline 6 & 25 & $60.79 \pm 0.62$ \\
\hline 7 & 50 & $63.82 \pm 1.12$ \\
\hline 8 & 100 & $66.84 \pm 1.61$ \\
\hline
\end{tabular}
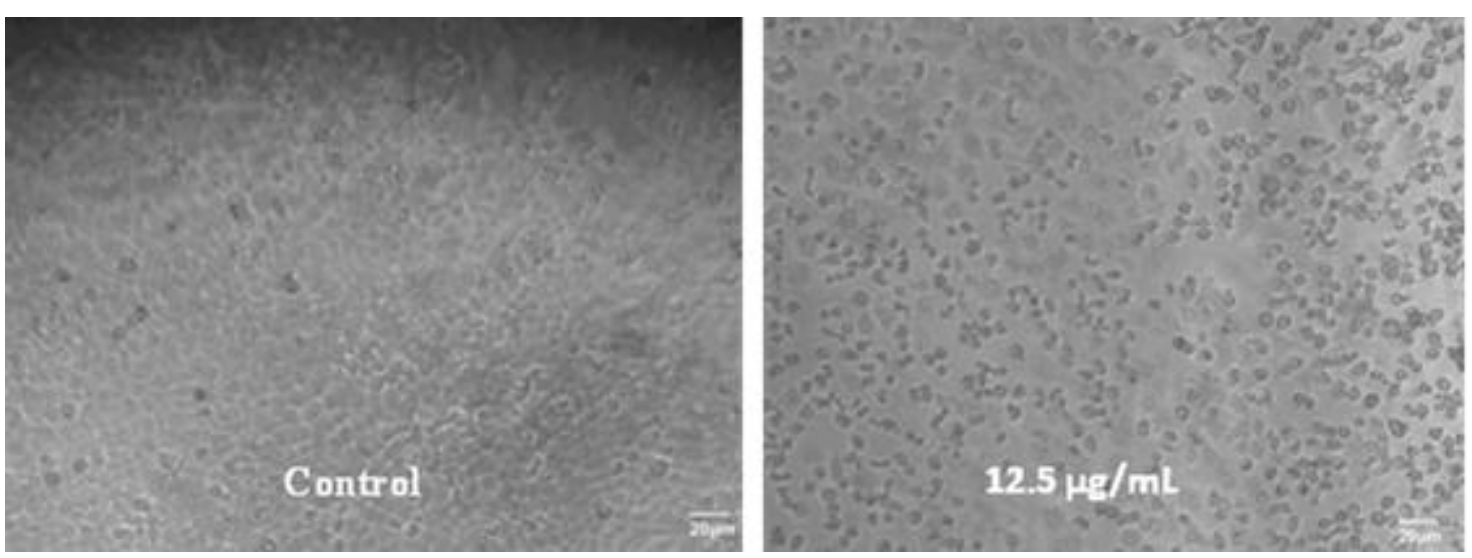

Volume 6 Issue 1, January 2017 www.ijsr.net 


\section{International Journal of Science and Research (IJSR) \\ ISSN (Online): 2319-7064}

Index Copernicus Value (2015): 78.96 | Impact Factor (2015): 6.391
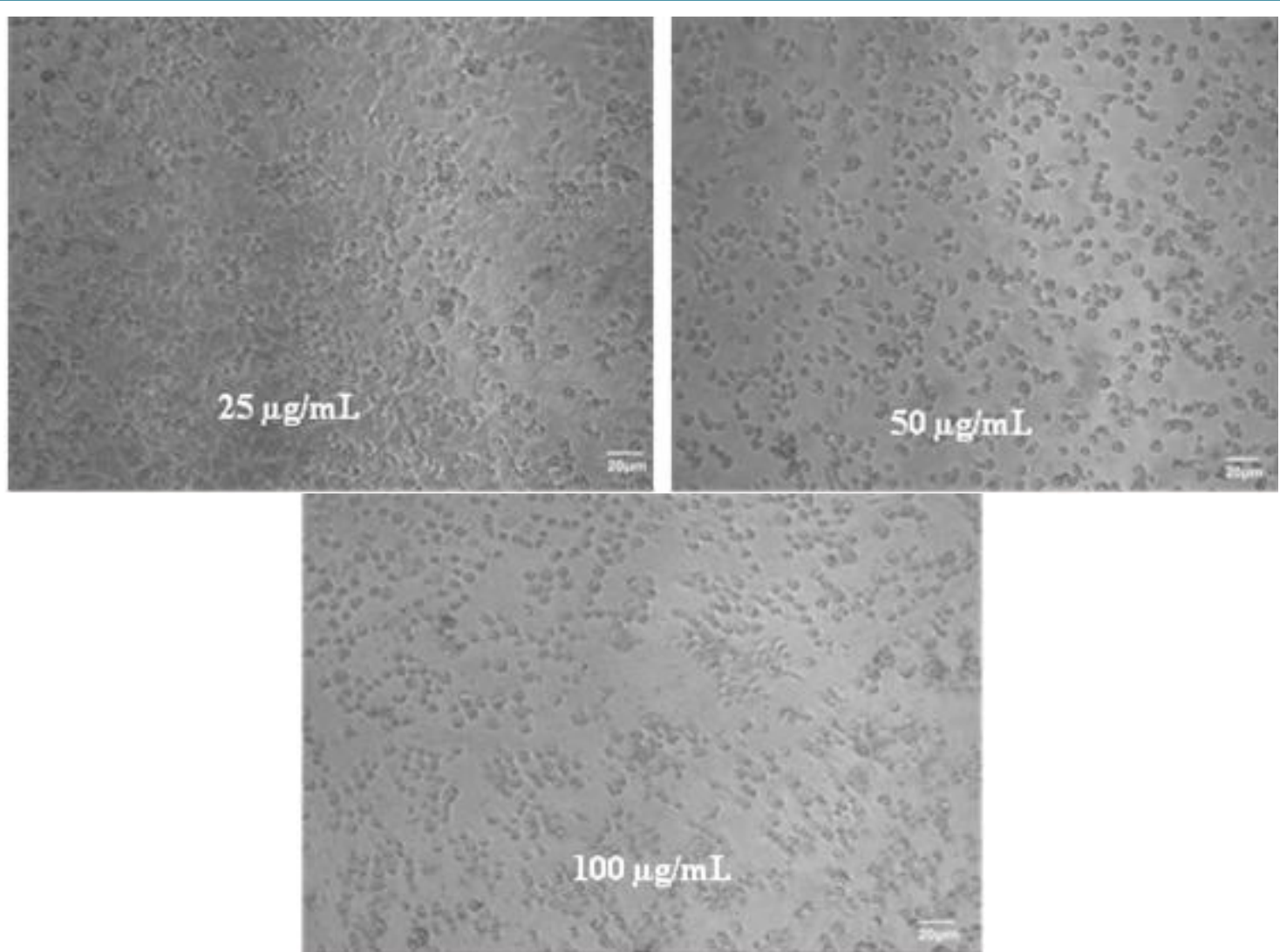

Figure 4: Cytotoxic effects of methanol extract of $M$. corchorifolia on MCF7 cell line

\section{Discussion}

Cancer is a severely debilitating disease and remains to be one of the leading causes of morbidity and mortality worldwide. It is a complex disease and several molecular targets need to be identified to successfully reduce the severity of the disease. The important hallmarks of cancer that enable tumour growth and metastatic dissemination are excessive proliferative signalling, evading growth suppressors, resisting cell death, inducing angiogenesis, enabling replicative mortality, activating invasion and metastasis. ${ }^{[15]}$ Also, tumour cells have developed single and multi-drug resistance. New anticancer drugs have to be developed which should have the potential to target these hallmarks of cancer and should be able to overcome resistance developed by tumour cells. Advanced cancer remains untreatable and there is continued searching for safer and effective drugs. Conventional therapies such as chemotherapy, radiation therapy and surgery produce serious side effects. Cancer chemoprevention with natural phytochemical compounds is an emerging strategy to prevent, delay or cure cancer. ${ }^{[16]}$

Many therapeutic drugs are obtained from plants and they are found to have the efficacy to treat cancer by targeting several pathways. Taxol, an active substance, obtained from the bark of the Pacific Yew tree (Taxus brevifolia) was found to be very efficient in arresting cell cycle by blocking microtubule depolarization and is presently used as a drug of reference in finding out the efficacy of new substances developed for the treatment of breast and ovary cancers. ${ }^{[17]}$ There are several plant-derived anticancer agents in the market today. Some of them are the vinca alkaloids (Vinblastine, Vincristine and Vindesine), the epipodophyllotoxins (Etoposide and Teniposide), the taxanes (Paclitaxel and Docetaxel) and the camptothecin derivatives (Camptothecin and Irinotecan). ${ }^{[18]}$

Many studies have suggested the existence of cancer stem cells (CSCs) in many types of tumours and are considered responsible for tumour relapse and resistance to chemo and radiotherapy. ${ }^{[19-21]}$ The dietary compounds including curcumin, sulforaphane, soy isoflavone, epigallocatechin-3gallate, resveratrol, lycopene, piperine and vitamin $\mathrm{D}_{3}$ are known to affect cancer stem cell self-renewal pathways. ${ }^{[22]}$ Curcumin and piperine have been shown to target breast cancer stem cells. ${ }^{[23]}$

Plants are the main part of our everyday diet and they possess nutritional properties that are studied over many years. Umar et al (2007) reported that the leaves of $M$. corchorifolia can be used as a protein supplement, sources of dietary lipids, fiber and minerals. ${ }^{[2]}$ The antibacterial and antihelmintic activities were also studied and it was found to possess significant activity. ${ }^{[25]}$ Although the plant is widely used in Malaysia, Indo-China, India, West Africa and in many other countries, ${ }^{[3]}$ people have to be cautious and several studies have to be performed to evaluate and prove the pharmacological uses of the plant. In the present investigation, the antioxidant and anticancer activities of the plant were studied and its chemical components were analysed through $\mathrm{GC} / \mathrm{MS}$ technique. The anticancer activity of methanol extract of the plant was studied for MCF7 (breast cancer) cell line by MTT assay method. In vitro antioxidant assays showed potent antioxidant activity for the plant. The methanol extract of $M$. corchorifolia exhibited significant cytotoxic effects. Cytotoxic changes including cell aggregation, cell rounding and cell death were observed

\section{Volume 6 Issue 1, January 2017}




\section{International Journal of Science and Research (IJSR) \\ ISSN (Online): 2319-7064}

Index Copernicus Value (2015): 78.96 | Impact Factor (2015): 6.391

in MCF7 cell line when treated with different concentrations of methanol extract of $M$. corchorifolia. Cells lost their typical morphology and appeared smaller in size. The extract reduced the cell viability in a concentrationdependent manner.

Adulteration, inappropriate formulation and lack of understanding of plant and drug interactions have led to adverse reactions that are sometimes life-threatening or lethal. Traditional herbal medicines are found to be safe when formulated and prescribed appropriately. [26] Preliminary laboratory studies are essential to confirm safety before clinical trials can be considered and well-designed clinical trials are needed to determine the safety and efficacy of each plant before they can be recommended for medical use. ${ }^{[27]}$

\section{Conclusion}

The results of the present study indicate that methanol extract of $M$. corchorifolia has significant inhibitory effect on the growth and proliferation of MCF7 cell line. Further molecular studies are required to find out the mechanism of action of bioactive compounds present in M. corchorifolia before it can be recommended for any practical widespread use of the plant. The results of various experiments conducted in the present investigation provide promising guideline regarding the potential uses of $M$. corchorifolia.

\section{Conflict of Interest}

There is no conflict of interest in the present research work.

\section{References}

[1] Smita A, Sonia C, Satyanarayana L. Breast and cervical cancer risk in India: An update. Indian J Public Health. 2014; 58(1): 5-10.

[2] Sasco AJ. Epidemiology of breast cancer: an environmental disease? Acta Pathol Microbiol Et Immunol Scandi. 2001; 109(5): 321-32.

[3] Pullaiah T. Ethnobotany, phytochemistry and pharmacology of Melochia corchorifolia L. Int Res J Pharm. 2014; 5(7): 543-5

[4] Trease GE, Evans WC. Textbook of Pharmacognosy. London: Balliese Tindall and Company Publisher; 1983. p. 343-83.

[5] Harbome JB. Phytochemical Methods. London: Chapman and Hall Ltd; 1973.p. 49-188.

[6] Raaman N. Phytochemical techniques. New Delhi: New India Publishing Agency;2006.p. 306.

[7] Blois MS. Antioxidant determinations by the use of a stable free radical. Nature. 1958; 181(4617): 1199-200.

[8] Delgado AC, Morales FJ. Unraveling the contribution of melanoidins to the antioxidant activity of coffee brews. J Agric Food Chem. 2005; 53(5): 1403-7.

[9] Olabinri BM, Odedire OO, Olaleye MT, Adekunle AS, Ehigie LO, Olabinri PF. In vitroevaluation of hydroxyl and nitric oxide radical scavenging activities of artemether. Res J of Biol Sci. 2010; 5(1): 102-5.

[10] Prieto P, Pineda M, Anguilar M. Spectrophotometric quantitation of antioxidant capacity through the formation of a Phosphomolybdenum Complex: Specific application to the determination of Vitamin E. Anal Biochem. 1999; 269(2): 337-41.

[11] Yen GC, Chen HY. Antioxidant activity of various tea extracts in relation to their antimutagenicity. J Agri Food Chem. 1995; 43(1): 27-32.

[12] Gennaro AR. Remington-The Science and Practice of Pharmacy. U.S.A: Lippincott Williams and Wilkins; 2000.p. 606-9.

[13] Stahl E. Thin Layer Chromatography. New Delhi: Springer Pvt. Ltd; 2005. p. 85.

[14] Mossman T. Rapid colorimetric assay for cellular growth and survival: application to proliferation and cytotoxicity assays. J Immunol Methods. 1983; 65(1-2): 55-63.

[15] Douglas H, Robert AW. Hallmarks of Cancer: The Next Generation. Cell. 2011; 144(5): 646-74.

[16] Hu W, Tin OK, Limin S, Zhengyuen S, Francisco F, Jong HL, et al. Plants Against Cancer: A Review on Natural Phytochemicals in Preventing and Treating Cancers and Their Druggability. Anticancer Agents Med Chem. 2012; 12(10): 1281-305

[17] Dmitri OL, Valery MD. Anti-breast Cancer Agents Derived from Plants. Nat Prod Bioprospect. 2015; 5(1):116.

[18] Avni GD, Ghulam NQ, Ramesh KG, Mahmoud ET, Jaswant S, Ajit KS, et al. Medicinal Plants and Cancer Chemoprevention. Curr Drug Metab. 2008; 9(7): 581-91.

[19] O'Brien CA, Pollett A, Gallinger S, Dick JE. A human colon cancer cell capable of initiating tumour growth in immunodeficient mice. Nature. 2007; 445(7123): 106-10.

[20] Schatton T, Murphy GF, Frank NY, Yamaura K, WaagaGasser AM, Gasser M, et al. Identification of cells initiating human melanomas. Nature. 2008; 451(7176): 345-9.

[21] Pistollato F, Giampieri F, Battino M. The use of plantderived bioactive compounds to target cancer stem cells and modulate tumor microenvironment. Food Chem Toxicol. 2015; 75: 58-70.

[22] Li Y, Wicha MS, Schwartz SJ, Sun D. Implications of cancer stem cell theory for cancer chemoprevention by natural dietary compounds. J Nutr Biochem. 2011; 22(9): 799-806.

[23] Kakarala M, Brenner DE, Korkaya H, Cheng C, Tazi K, Ginestier $\mathrm{C}$, et al. Targeting breast stem cells with the cancer preventive compounds curcumin and piperine. Breast Cancer Res Treat. 2010; 122 (3): 777- 85

[24] Umar KJ, Hassan LG, Dangoggo SM, Inuwa M, Almustapha MN. Nutritional Content of Melochia corchorifolia (Linn.) Leaves. Int J Biol Chem. 2007; 1(4): 250-5.

[25] Palaksha MN, Ravishankar K, Girija SV. Evaluation of in vitro antibacterial and anthelmintic activities of Melochia corchorifoliaplant extracts. Int $\mathbf{J}$ of Biol \& Pharm Res 2013; 4(8): 577-81.

[26] Elvin-Lewis M. Should we be concerned about herbal remedies. J of Ethnopharmacol. (2001); 75(2-3): 141-64

[27] Vickers AJ. Which botanicals or other unconventional anticancer agents should we take to clinical trial?J Soc Integr Oncol. (2007); 5(3): 125-9.

\section{Corresponding Author}

Dr. C. Sivaraj, Postdoctoral Fellow, Department of Natural Products, Armats Biotek Training and Research Institute, No14/18C, Mettu Street, Link Road, Maduvankarai, Guindy, Chennai, 600032, Tamil Nadu, INDIA. Phone no: 91-9941764053 E-mail: shivaraj27@gmail.com

\section{Volume 6 Issue 1, January 2017

